Original Article

\title{
PRODUCTION OF PROTEASE FROM BACILLUS SUBTILIS UNDER SSF AND EFFECT OF ORGANIC SOLVENTS ON LYOPHILIZED PROTEASE PREPARATIONS
}

\author{
SELMIHAN SAHIN*, YASEMİN DEMIR, ISMAIL OZMEN
}

Suleyman Demirel University, Arts and Sciences Faculty, Department of Chemistry, Cunur, Isparta, 32260, Turkey

*Email: selmihansahin@sdu.edu.tr

Received: 10 Nov 2019 Revised and Accepted: 29 Feb 2020

ABSTRACT

Objective: In the present work, protease was produced from Bacillus subtilis under solid-state fermentation (SSF). The effect of lyophilization with different additives on the activity of protease in an organic solvent and kineteci properties was investigated.

Methods: Production conditions of protease (fermentation time, moisture level, initial $\mathrm{pH}$, temperature) were optimized. After production, it was partially purified and then, lyophilized with different additives from an aqueous buffer solution containing 98\% (w/w) of different additives (pumice, $\mathrm{KCl}$, without additive) for $72 \mathrm{~h}$ after freezing in liquid nitrogen. After that, the effect of organic solvents (2.5\% and $5 \%$ of DCM, ethanol, hexane, toluene) on these lyophilized protease preparations was determined and their kinetic properties were determined.

Results: Optimum protease production was obtained with $40 \%$ of moisture level, at $\mathrm{pH} 7.5,37^{\circ} \mathrm{C}$ after $24 \mathrm{~h}$ fermentation. It was partially purified by using ammonium sulphate precipitation (20-80\%) with 5.8-fold and specific activity of $38 \mathrm{U} / \mathrm{mg}$ and then dialysed with 6.4 -fold and a specific activity of $35 \mathrm{U} / \mathrm{mg}$. Co-lyophilization of protease with pumice and $\mathrm{KCl}$ was increased activity of an enzyme in aqueous organic solvents when compared lyophilized protease without additive. Used solvents, except DCM, were increased activity of lyophilized protease with pumice/KCl. It was found that the lyophilization with pumice and $\mathrm{KCl}$ resulted in an increasing in the catalytic efficiency, while it was decreased in $\mathrm{Km}$ and $\mathrm{Vmax}$ values.

Conclusion: The obtained findings demonstrated that protease from B. subtilis can effectively be produced under SSF by using wheat bran and used in industrial applications because of showing improved activity in an organic solvent by co-lyophilization with pumice/KCl.

Keywords: Bacillus Subtilis, Lyophilization, Organic Solvent, Pumice, Protease

(C) 2020 The Authors. Published by Innovare Academic Sciences Pvt Ltd. This is an open access article under the CC BY license (http://creativecommons.org/licenses/by/4.0/) DOI: http://dx.doi.org/10.22159/ijcr.2020v4i2.104. Journal homepage: https://ijcr.info/index.php/journal

\section{INTRODUCTION}

Proteases are one of the most prestigious groups of industrial enzymes. They constitute $60 \%$ of the global industrial enzyme market. Although proteases can be produced in all organisms [1], microorganisms produce enzymes easily and faster among them, and enzyme production can be performed at any time and do not affected by seasonal fluctuations. Furthermore, extracellular production of enzymes by microorganisms provides advantages like simple downstream processing and decreasing the costs [2]. The genus Bacillus is the most prominent source of protease with high yield [2-4]. Protease production from bacteria is generally performed with submerged fermentation (SmF) in shake flasks or fermenters [5]. But, there are also studies on the production of protease by solid-state fermentation (SSF) [1, 5-8]. SSF has several advantages such as low production cost, low water and energy requirements, decrease extensive downstream processing and waste generation, improve product stability. Based on these, SSF has gained more interest for several industrial applications [1,9].

Enzyme catalysis in low water containing organic solvents has gained considerable attention due to its advantages such as high selectivity, thermostability and reduced side reactions in numerous synthetic and biologic catalysis [10,11]. However, the industrial application of enzymes is limited in such media because many enzymes have relatively low catalytic activity [12]. Therefore, many strategies can be performed to enhance enzyme activity, stability, and enantioselectivity. Some of these strategies were supposed to activate enzymes in organic media, like salt activation, chemical modification and immobilization of enzymes $[11,13]$. Especially, the co-lyophilization of enzymes with inorganic salts from aqueous solution is found remarkably effective in terms of activation. Previously, it was reported that catalytic activity of subtilisin Carlsberg (SC) in different organic solvents was increased almost 4000-fold by addition of $98 \mathrm{wt} \%$ of $\mathrm{KCl}$ [14] and 27000-fold in hexane with the optimized condition [15]. Lindsay et al. [16] have revealed that a formulation consisting of $98 \%(\mathrm{w} / \mathrm{w})$ of a $1: 1 \mathrm{KAc}$ : $\mathrm{CsCl}$ salt-containing penicillin amidase preparation was 35,000-fold more active than the salt-free formulation in hexane. In addition that, thermolysin [17], a-chymotrypsin [14], Mucor javanicus lipase [18], and penicillin amidase [19] activity have been studied in organic solvents. Furthermore, fumed silica has been used to activation of Candida antarctica Lipase B (CALB) [13] and subtilisin Carlsberg [12, 20]. Based on these studies, natural porous silica based material, pumice, was used to activation of protease from $B$. subtilis in this study.

The first aim of this study was to optimize protease production from $B$. subtilis under SSF by using wheat bran as a carbon source. The other aim was to determine the effect of co-lyophilization with pumice on protease activity in an organic solvent and compare it with co-lyophilized enzyme preparations with $\mathrm{KCl}$ and without additive.

\section{MATERIALS AND METHODS}

$\mathrm{KH}_{2} \mathrm{PO}_{4}, \mathrm{KCl}$, ethanol, hexane, toluene and DCM were obtained from Merck. All other chemicals used were of analytical grade. B. subtilis $\mathrm{M}-11$ was used as enzyme producer microorganism [21]. Pumice (NMP-6; 0-180 $\mu \mathrm{m}$ ) obtained from the region of Nevsehir from Turkey.

\section{Enzyme production}

The protease was obtained by SSF using wheat bran. The culture medium was composed of 5 g of the substrate (dry weight) and the moisture content was adjusted by using $50 \mathrm{mmol}$ of $\mathrm{KH}_{2} \mathrm{PO}_{4}$ buffer ( $\mathrm{pH}$ 7.5). Erlenmeyer flask containing the culture medium was autoclaved, then 
subsequently inoculated with cell suspension of $B$. subtilis, followed by incubation at $37{ }^{\circ} \mathrm{C}$ for $24 \mathrm{~h}$. At the end of the fermentation, culture was extracted with $50 \mathrm{ml}$ of $\mathrm{KH}_{2} \mathrm{PO}_{4}$ buffer ( $\mathrm{pH} \mathrm{7.5)} \mathrm{by} \mathrm{shaking} \mathrm{for} 1$ h. The culture mixture was centrifuged at 8000 rpm for 20 min at room temperature. The supernatant used as crude enzyme extract. All data represent the mean ( \pm standard deviation, SD) of three independent experiments.

\section{Partial purification of protease}

Proteins were precipitated from the crude enzyme extract at 60-80\% saturation and were collected by centrifugation (8000 rpm, 20 min). After that, precipitated proteins were redissolved in a small amount of $50 \mathrm{mmol} \mathrm{KH}_{2} \mathrm{PO}_{4}$ buffer (pH 7.5) and then dialyzed against the same buffer.

\section{Protease activity}

Protease activity was measured as previously reported by the methods of Cupp-Enyard [22] with small modifications [21].

\section{Enzyme preparation}

The partial purified protease solution was lyophilized with $98 \%$ of $\mathrm{KCl} /$ pumice or without any additive. Enzyme solutions were shaken at $25{ }^{\circ} \mathrm{C}$, frozen with liquid nitrogen for $20 \mathrm{~min}$, and then lyophilized in a freeze-drier for $72 \mathrm{~h}$ [12]. Lyophilized protease preparations were used for the proteolytic activity reaction after pre-equilibration at the desired water activity.

The effect of organic solvents (ethanol, hexane, toluene and DCM) on lyophilized protease preparations were evaluated by adding 2.5 and $5 \%$ (v/v) of the solvent in the activity assay. The activity of the lyophilized protease preparations without solvent was taken as $100 \%$.

\section{Kinetic studies}

The kinetic constants were determined for three lyophilized protease preparations using casein as a substrate at different concentrations ranging from $0.13 \%-6.5 \%$ at $37{ }^{\circ} \mathrm{C}$ and $\mathrm{pH} 7.5$ for 10 min. Maximal reaction (Vmax) and Michaelis-Menten constant $(\mathrm{Km})$ values were calculated by Michaelis-Menten plots. The value of the catalytic efficiency $(\mathrm{Vmax} / \mathrm{Km}$ ) was calculated.

\section{RESULTS AND DISCUSSION}

SSF processes can be affected by several important factors such as strain, the substrate for enzyme production and physical, chemical and biochemical process parameters. To optimize the SSF conditions for the production of the protease from $B$. subtilis, fermentation time, moisture level (\%), initial pH of the substrate, and temperature of incubation were studied. These are described as below.

\section{Effect of fermentation time on protease production}

The SSF medium was inoculated with the bacterial strain and incubated for various time intervals (12 h-36 h). The enzyme production was gradually increased with time and the highest enzyme activity (428 $\left.\pm 36 \mathrm{U} \mathrm{ml}^{-1}\right)$ was obtained for $24 \mathrm{~h}$ of incubation (fig. 1). A decreasing in the enzyme activity was also observed with prolonged incubation. There is a need a certain extent for the production of enzyme and the other metabolites. When the nutrients for the microorganism start to decrease, the enzyme production starts to decrease [5].

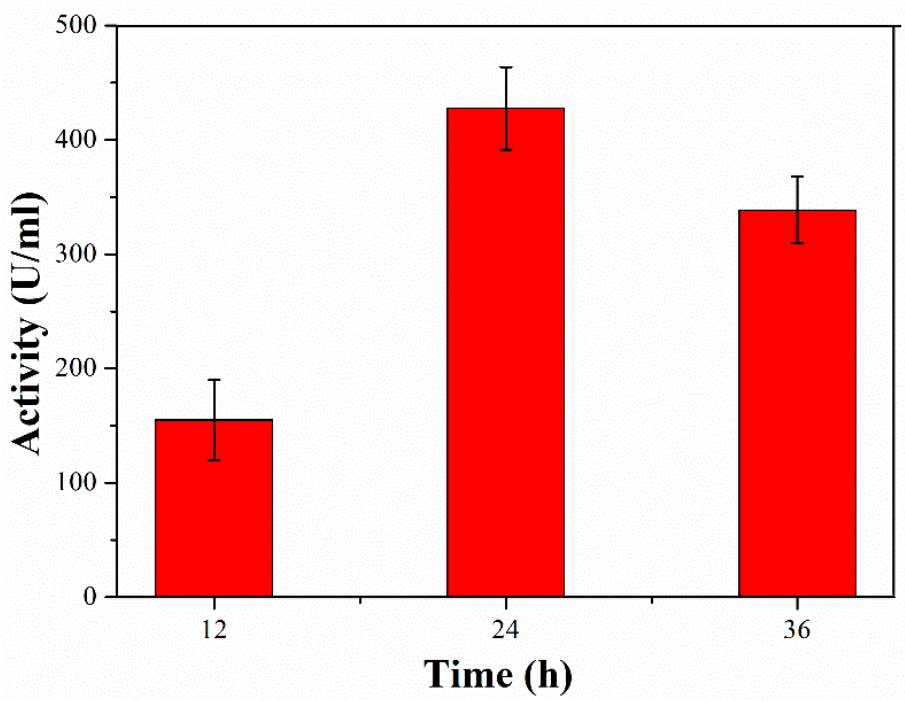

Fig. 1: Effect on time on protease production from B. subtilis. All values are expressed as mean \pm SEM $(n=3)$

\section{Effect of moisture level on protease production}

Among the several factors, the initial moisture content is one of the most critical factor for the microbial growth and enzyme production under SSF $[6,23]$. Water content in the medium provide the nutrients more easily accessible for microorganisms. However, high level of water can adversely affect oxygen diffusion in the substrate [23]. In this study, the maximum production of protease from $B$. subtilis was observed in the $40 \%$ moisture level under SSF (fig. 2). The activity of protease was decreased attributed to oxygen transfer limitation because of the high level of water with an increased level of moisture. Moreover, it could be said that 30\% of the moisture level is too low for the B. subtilis growth. Previously, Saminathan and Sriman [24] were reported that the protease production was highest in the $20-40 \%$ moisture level from B. subtilis IAS01 using agro-industrial by-product under SSF. 


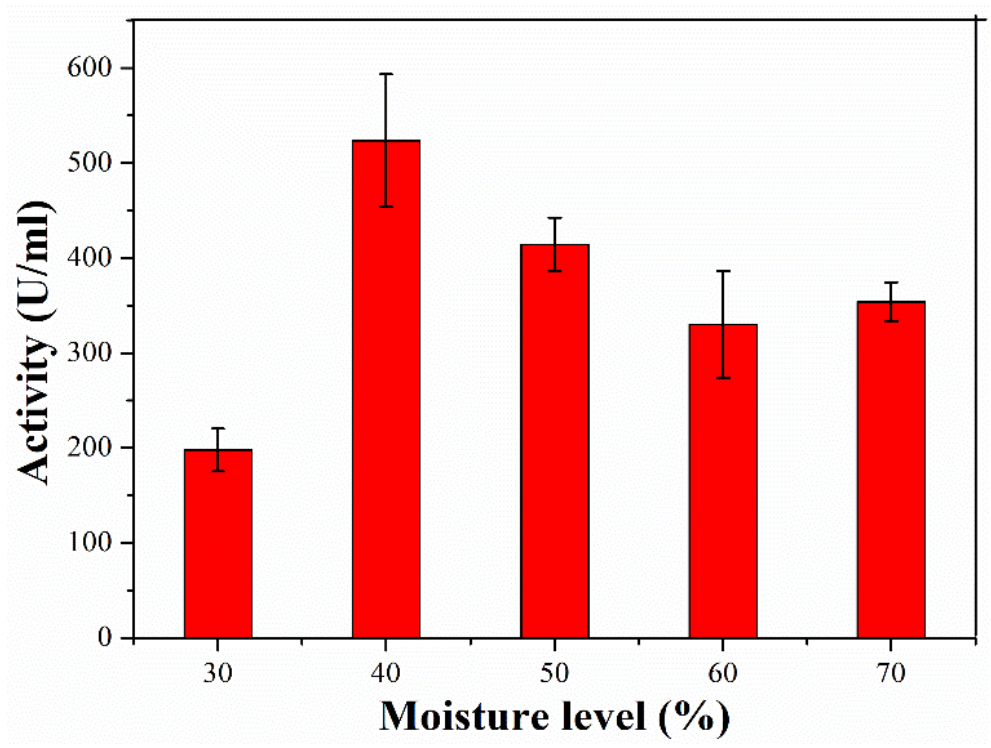

Fig. 2: Effect of moisture level on protease production from $B$. subtilis. All values are expressed as mean \pm SEM $(n=3)$

\section{Effect of initial $\mathrm{pH}$ on protease production}

The effect of initial $\mathrm{pH}$ values on protease production is shown in fig. 3. While the protease production was optimum at $\mathrm{pH} 7.5$, it decreased at $\mathrm{pH} 6.5$ and 8.5. This could be attributed to the slow growth of bacterium at lower and higher $\mathrm{pHs}$ [24]. Therefore, the initial pH of the fermentation medium was kept at $\mathrm{pH} 7.5$ in further experiments.

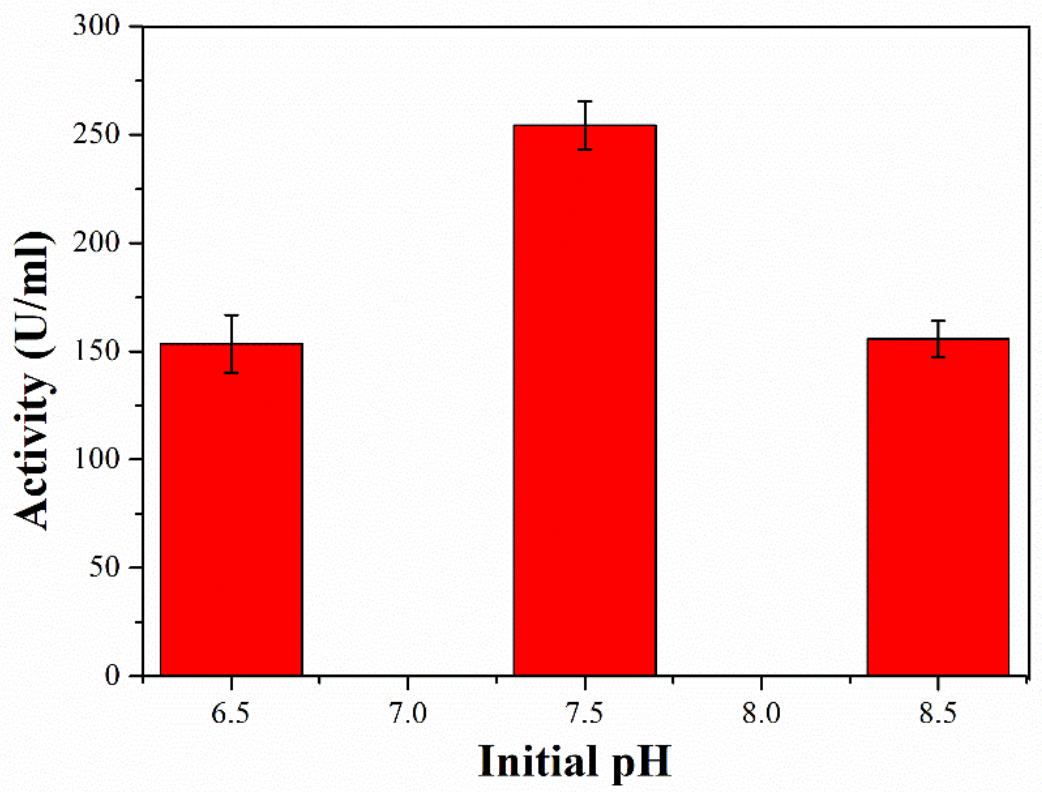

Fig. 3: Effect of initial $\mathrm{pH}$ on protease production from $B$. subtilis. All values are expressed as mean \pm SEM $(\mathrm{n}=3)$

\section{Effect of temperature on protease production}

The temperature of the fermentation affected the protease activity, as shown in fig. 4. The enzyme production by $B$. subtilis reached the highest value at the $37^{\circ} \mathrm{C}$. The enzyme production was slightly decreased at $27^{\circ} \mathrm{C}$ and $47^{\circ} \mathrm{C}$. Saba et al.[5] reported optimum alkaline protease production by B. subtilis under SSF at $37^{\circ} \mathrm{C}$. However, above $37^{\circ} \mathrm{C}$ and up to $50^{\circ} \mathrm{C}$, there was a marked decrease in the biosynthesis of alkaline protease by $B$. subtilis due to higher temperatures may cause an adverse effect on microorganism, respectively. 


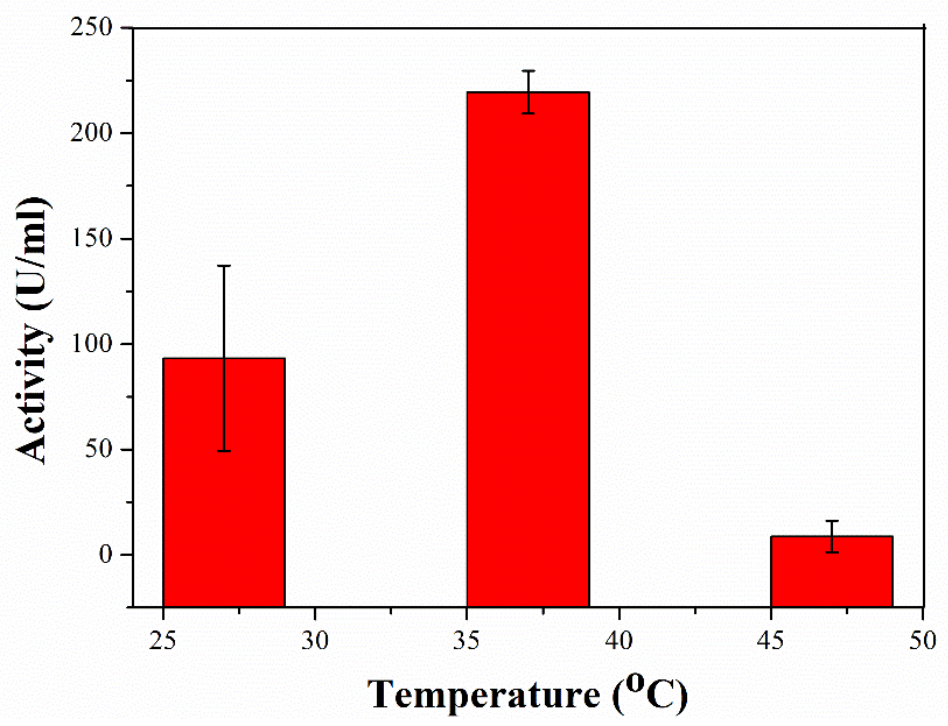

Fig. 4: Effect of temperature on protease production from $B$. subtilis. All values are expressed as mean \pm SEM $(n=3)$

\section{Partial purification of protease}

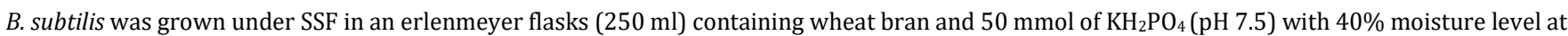
$37{ }^{\circ} \mathrm{C}$ and pH 7.5 for $24 \mathrm{~h}$. The culture was extracted with $50 \mathrm{mmol}$ of $\mathrm{KH}_{2} \mathrm{PO}_{4}(\mathrm{pH} 7.5$ ) and centrifuged at 8000 rpm for 30 min. The supernatant was subjected to $20-80 \%$ ammonium sulfate precipitation and then centrifuged at 8000 rpm for 30 min. The obtained precipitates were dissolved in 50 mmol of $\mathrm{KH}_{2} \mathrm{PO}_{4}\left(\mathrm{pH} \mathrm{7.5)}\right.$ and dialyzed against the same buffer for $24 \mathrm{~h}$ at $4{ }^{\circ} \mathrm{C}$. After dialysis, protease was purified 6.4 -fold with $35 \%$ yield from the supernatant. The summary of the partial purification of protease from $B$. subtilis is given in table 1 .

Table 1: The summary of the partial purification of protease from $B$. subtilis

\begin{tabular}{|c|c|c|c|c|c|}
\hline Steps & Total protein (mg) & Total activity (U) & Specific activity (U/mg) & Yield (\%) & Purification fold \\
\hline Supernatant & 910 & 148.850 & 16 & 100 & 1 \\
\hline Ammonium sulfate precipitation & 600 & 56.460 & 94 & 38 & 5.8 \\
\hline Dialysis & 498 & 51.450 & 103 & 35 & 6.4 \\
\hline
\end{tabular}

\section{Organic solvents effect on lyophilized protease preparations}

The solvents (Ethanol, hexane, toluene and DCM) were used to study their effects on the differently lyophilized protease preparations. The activity of the enzymes was assayed in the presence of varying concentrations ( 2.5 and $5 \% \mathrm{v} / \mathrm{v})$ of these solvents added in the standard assay mixture. Table 2 shows the effect of different concentrations of organic solvents on the proteolytic activity of lyophilized enzyme preparations.

Table 2: Relative activity of lyophilized protease preparations in presence of different organic solvents at concentrations of 2.5 and $5 \%$ $(\mathrm{v} / \mathrm{v})$

\begin{tabular}{llll}
\hline & Enzyme (\%) & Pumice (\%) & KCl (\%) \\
\hline None & $100 \pm 3.7$ & $100 \pm 3.5$ & $100 \pm 12$ \\
$2.5 \%$ & & & $63 \pm 21$ \\
DCM & $29 \pm 13$ & $45 \pm 12$ & $112 \pm 15$ \\
Ethanol & $65 \pm 4.5$ & $130 \pm 14$ & $129 \pm 6.3$ \\
Hexane & $75 \pm 4.4$ & $157 \pm 11$ & $116 \pm 9.3$ \\
Toluen & $51 \pm 6.6$ & $120 \pm 14$ & $45 \pm 4.4$ \\
$5 \%$ & & & $128 \pm 7.4$ \\
DCM & $24 \pm 8.6$ & $36 \pm 13$ & $153 \pm 7.6$ \\
Ethanol & $59 \pm 10$ & $133 \pm 11$ & $176 \pm 6.7$ \\
Hexane & $92 \pm 3.7$ & $140 \pm 1.6$ & \\
Toluen & $78 \pm 6.3$ & & \\
\hline
\end{tabular}

*All values are expressed as mean $\pm \operatorname{SEM}(\mathrm{n}=3)$.

All used solvents have decreased proteolytic activity of lyophilized enzyme preparation without additives (table 2, None). DCM as a polar aprotic solvent decreased proteolytic activity of all lyophilized enzyme preparations at $2.5 \%$ and $5 \%$ (v/v) of concentration. Badgujar et al. [25] reported that the proteolytic activity of cysteine protease was decreased with DCM. Ethanol as hydrophilic organic solvent and hexane and toluene as aprotic nonpolar organic solvents have increased proteolytic activity of lyophilized enzyme preparations with pumice and KCl. Previously, Hermanova et al.[26] showed that lipase immobilized on graphene oxide showed increased hydrolytic activity in a non-polar solvent (toluen, n-hexane). 
Furthermore, the proteolytic activity of lyophilized enzyme preparations with pumice and $\mathrm{KCl}$ increased with increasing concentration of solutions. Also, a co-lyophilized protease with pumice gave more increased catalytic activity in aqueous organic solvents than co-lyophilized protease with $\mathrm{KCl}$. It was reported that the addition of kosmotropic salts stabilizes the native form of the enzyme against denaturation because they have strong interactions with water and increase its surface tension $[15,16]$. Based on this, it can be said that pumice also provided a similar effect on proteolytic activity. Catalysis in organic media with enzymes can provide important advantages in industrial applications. But, there are some difficulties due to enzymes that have low activity and instability in organic media [3]. The results showed that co-lyophilization of protease with pumice and $\mathrm{KCl}$ improved the catalytic activity in the presence of $2.5 \%$ and $5 \%$ of organic solvents when compared with lyophilized protease without additive (table 2, Enzyme).

\section{Kinetic studies}

The kinetic parameters ( $\mathrm{Km}$ and $\mathrm{Vmax}$ ) of the lyophilized protease preparations (consisting of $98 \% \mathrm{KCl}, 98 \%$ pumice, no addition) were also studied by using casein as a substrate. The kinetic parameters were calculated using Michaelis-Menten plots (fig. 5). Km, Vmax and catalytic efficiency values were given in table 3. It was found that the lyophilization with $\mathrm{KCl}$ and pumice resulted in an increasing in catalytic efficiency, while there is a decreasing in Km and Vmax values. Previously, Cruz et al. [13] obtained similar results with fumed silica. It can be said that lyophilization of enzyme with $\mathrm{KCl}$ and pumice enhanced the catalytic activity of the enzyme. Protease lyophilized with $\mathrm{KCl}$ showed higher catalytic efficiency compared with lyophilized with pumice and without additive enzyme preparations. Ru et al. [27] indicated that $\mathrm{KCl}$ produced the greatest activation for subtilisin Carslberg.

Table 3: Km, Vmax and catalytic efficiency values of lyophilized protease preparations

\begin{tabular}{llll}
\hline Sample & $\operatorname{Vmax}(\boldsymbol{U} / \boldsymbol{m l})$ & Km $(\%$ casein) & Catalytic efficiency (Vmax/Km) \\
\hline None & $1260 \pm 202$ & $2.40 \pm 0.70$ & 525 \\
Pumice & $1245 \pm 146$ & $2.30 \pm 0.53$ & 541 \\
KCl & $926 \pm 100$ & $1.10 \pm 0.24$ & 841 \\
\hline
\end{tabular}

*All values are expressed as mean \pm SEM $(n=3)$.
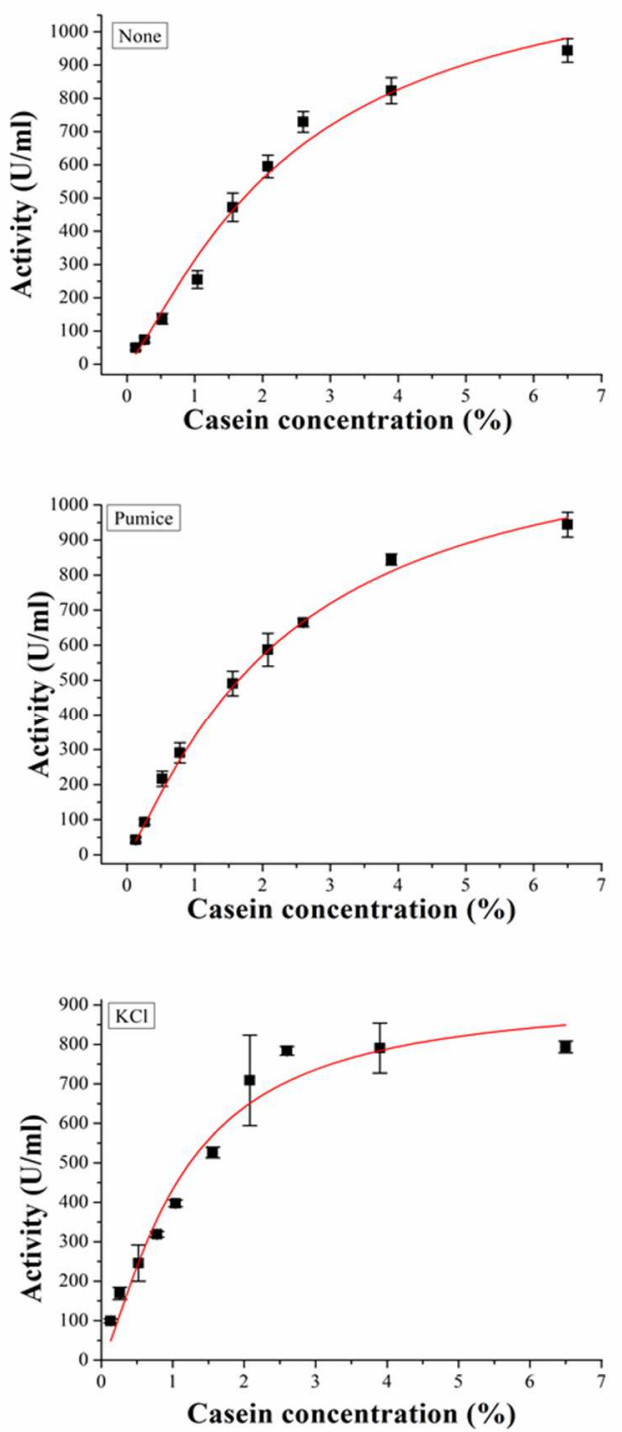

Fig. 5: Michaelis-menten plots of lyophilized protease preparations 


\section{CONCLUSION}

In the present study, optimum conditions of protease production from $B$. subtilis under SSF were determined as $\mathrm{pH} 7.5,37{ }^{\circ} \mathrm{C} 40 \%$ moisture level and $24 \mathrm{~h}$. Effect of organic solvents (Ethanol, hexane, toluene, DCM) was studied on lyophilized protease with pumice, KCl and without additive. The obtained protease showed improved activity in organic solvents (2.5 and 5\%) by co-lyophilization in the presence of pumice/KCl. Especially, colyophilized protease with pumice displayed higher catalytic activity. In addition that, a co-lyophilized protease with pumice/KCl displayed higher catalytic efficiency $\left(V_{\max } / K_{m}\right)$. Using enzyme in organic media has several advantageous such as increased solubility of substrate, suppression of water-dependent side reactions might occur, alteration of substrate specify, potential for enzymes to be used directly in a chemical process. Improving the activity and stability of the enzyme in organic media is important for different applications of biocatalytic reactions in pharmaceutical, food, and fine chemical industries. As conclusion, it can be said that co-lyophilized protease preparations in the presence of pumice/ $\mathrm{KCl}$ can play an important role in several industrial processes with their improved activity in organic media.

\section{FUNDING}

Nil

\section{AUTHORS CONTRIBUTIONS}

S. S. wrote the manuscript with support from I. O. S. S designed and performed the experiments. Y. D helped carry out the production of protease. I. O. supervised the project.

\section{CONFLICT OF INTERESTS}

\section{Declared none}

\section{REFERENCES}

1. Singh S, Bajaj BK. Bioprocess optimization for production of term alkali-stable protease from bacillus subtilis K-1 under solid-state fermentation. Prep Biochem Biotechnol 2016;46:717-24.

2. Contesini FJ, Melo RR, Sato HH. An overview of bacillus proteases: from production to application. Crit Rev Biotechnol 2018;38:321-34.

3. Gulmez C, Atakisi O, Dalginli KY, Atakisi E. A novel detergent additive: Organic solvent-and thermo-alkaline-stable recombinant subtilisin. Int J Biol Macromol 2018;108:436-43.

4. Ramakrishnan V, Thambidurai Y, Rajasekharan SK, Mohanvel SK. Partial characterization and cloning of protease from bacillus. Asian J Pharm Clin Res 2017;10:187.

5. Saba I, Hamid M, Ikram ulH. Production of alkaline protease by bacillus subtilis using solid-state fermentation. Afr J Microbiol Res 2013;7:1558-68.

6. Prakasham RS, Rao Ch S, Sarma PN. Green gram husk--an inexpensive substrate for alkaline protease production by bacillus sp. in solid-state fermentation. Bioresour Technol 2006;97:1449-54.

7. Mukherjee AK, Adhikari H, Rai SK. Production of alkaline protease by a thermophilic Bacillus subtilis under solid-state fermentation (SSF) condition using imperata cylindrica grass and potato peel as a low-cost medium: characterization and application of enzyme in detergent formulation. Biochem Eng J 2008;39:353-61.

8. Pant G, Prakash A, Pavani JVP, Bera S, Deviram GVNS, Kumar A, et al. Production, optimization and partial purification of protease from Bacillus subtilis. J Taibah Univ Sci 2018;9:50-5.

9. Pandey A. Solid-state fermentation. Biochem Eng J 2003;13:81-4.

10. Gupta MN, Roy I. Enzymes in organic media. Forms, functions and applications. Eur J Biochem 2004;271:2575-83.

11. Zhang L, Li Y, Yuan Y, Jiang Y, Guo Y, Li M, Pu X. Molecular mechanism of carbon nanotube to activate subtilisin carlsberg in polar and non-polar organic media. Sci Rep 2016;6:36838.

12. Pfromm PH, Rezac ME, Würges K, Czermak P. Fumed silica activated subtilisin Carlsberg in hexane in a packed-bed reactor. AIChE J 2007;53:237-42.

13. Cruz JC, Pfromm PH, Rezac ME. Immobilization of candida antarctica lipase b on fumed silica. Process Biochem 2009;44:62-9.

14. Khmelnitsky YL, Welch SH, Clark DS, Dordick JS. Salts dramatically enhance the activity of enzymes suspended in organic solvents. J Am Chem Soc 1994;116:2647-8

15. Ru MT, Hirokane SY, Lo AS, Dordick JS, Reimer JA, Clark DS. On the salt-induced activation of lyophilized enzymes in organic solvents: effect of salt kosmotropicity on enzyme activity. J Am Chem Soc 2000;122:1555-71.

16. Lindsay JP, Clark DS, Dordick JS. Combinatorial formulation of biocatalyst preparations for increased activity in organic solvents: salt activation of penicillin amidase. Biotechnol Bioeng 2004;85:553-60.

17. Khmelnitsky YL, Budde C, Arnold JM, Usyatinsky A, Clark DS, Dordick JS. Synthesis of water-soluble paclitaxel derivatives by enzymatic acylation. J Am Chem Soc 1997;119:11554-5.

18. Altreuter DH, S DJ, Clark DS. Nonaqueous biocatalytic synthesis of new cytotoxic doxorubicin derivatives: exploiting unexpected differences in the regioselectivity of salt-activated and solubilized subtilisin. J Am Chem Soc 2002;24:1871-6.

19. Lindsay JP, Clark DS, Dordick JS. Penicillin amidase is activated for use in nonaqueous media by lyophilizing in the presence of potassium chloride. Enzyme Microb Technol 2002;31:193-7.

20. Würges K, Pfromm PH, Rezac ME, Czermak P. Activation of subtilisin carlsberg in hexane by lyophilization in the presence of fumed silica. J Mol Catal B: Enzym 2005;34:18-24.

21. Sahin S, Ozmen I, Kir E. Purification, immobilization, and characterization of protease from local Bacillus subtilis M-11. Asia Pac J Chem Eng 2015;10:241-7.

22. Cupp Enyard C. Sigma's non-specific protease activity assay-casein as a substrate. J Vis Exp 2008;17:pii899.

23. Chutmanop J, Chuichulcherm S, Chisti Y, Srinophakun P. Protease production by aspergillus oryzae in solid-state fermentation using agroindustrial substrates. J Chem Technol Biotechnol 2008;83:1012-8.

24. Saminathan D, J SN. Optimization and production of alkaline protease from Bacillus subtilis IAS01 using agro-industrial by-product under SSF. Int Res J Biol Sci 2015;4:60-4.

25. Badgujar SB, Mahajan RT. Characterization of thermo-and detergent stable antigenic glycosylated cysteine protease of Euphorbia nivulia Buch.-Ham. and evaluation of its eco-friendly applications. Sci World J 2013;716545.

26. Hermanova S, Zarevucka M, Bousa D, Pumera M, Sofer Z. Graphene oxide immobilized enzymes show high thermal and solvent stability. Nanoscale 2015;7:5852-8.

27. Ru MT, Wu KC, Lindsay JP, Dordick JS, Reimer JA, Clark DS. Towards more active biocatalysts in organic media: increasing the activity of saltactivated enzymes. Biotechnol Bioeng 2001;75:187-96. 